\title{
Talking about Ideological and political curriculum teaching mode reform way Yang Pan
}

\author{
Ideological and political Teaching, XiJing University, Shaanxi ,710123,China
}

Keywords: curriculum reform; ideological and political course; quality education; Countermeasures

\begin{abstract}
. under the background of the new education reform, the ideological and political course teaching reform is imperative, in the standard curriculum, educational content, teaching methods and teaching evaluation should be improved. But there are still many problems, such as academic position are not valued; teachers team Wu Shuiping needs to be improved; curriculum evaluation system is not scientific; single subject teaching methods, teaching mode can not adapt to the development of information technology needs. Deepen the reform of political course, it is necessary to raise the status of political lesson teaching, strengthen the building of the contingent of teachers, attention to the students' ability cultivation and improve the comprehensive quality of the students. Should also pay attention to the reform of the curriculum evaluation system, enrich the teaching Method, make the ideological and political course glow with the charm of the subject, and promote the comprehensive development of students.
\end{abstract}

\section{Introduction}

The transformation of more than two thousand years of Chinese traditional education is also affected by the new education thoughts, the impact of education method and mode of running a school, of which the most influential is the rise of the quality education. In order to meet the challenge of knowledge economy, and comprehensively improve the national quality, enhance the comprehensive national strength, China began the full implementation of quality education, curriculum reform of basic education. The standard promotes the educators education idea transformation, guide the teaching reform and talent cultivation mode, widely recognized.

\section{Improve the quality of political teachers}

As the saying goes: "blacksmith first to its own hardware. To the full implementation of quality education. First of all, we should improve teachers' own quality. The quality of teachers mainly includes two aspects, one is its expertise to be solid, to constantly update, advancing with the times, and constantly improve the professional ability; the second is the cultivation of teachers' words and deeds, moral consciousness to improve. This is the basis of quality education and the implementation of quality education prerequisite. In order to improve the quality of teachers, teachers are required to efforts from the following aspects: first, insist on learning to continuously consolidate and enrich their professional knowledge. With the deepening of the reform of education and teaching, and political theory also in constantly enrich and develop. As political teachers unable to meet the academic standard and the original knowledge must be constantly learning, constantly update their knowledge and make their own understanding to adapt to the development need. Because the quality of teachers determines the recognition of curriculum development and utilization degree and to play a benefit level, the teacher is the curriculum of cooperation, the implementation of curriculum inquiry, as collaborators have a solid theoretical foundation, how to control the teaching material, as a study, have a solid theoretical knowledge and teaching skills, and how to tap the textbook, mobilize the enthusiasm of the students. Therefore, keep learning, continue to consolidate enrich their professional knowledge imminent. Second, dare to practice, not To continuously improve their business ability. Teachers have profound and deep knowledge of the subject, still need to the courage to practice, and constantly improve their operational capacity, which requires teachers to actively participate in teaching and research, combined with the actual, 
teach students in accordance with their aptitude, be good at summing up, continuously explore and master the good method of teaching, effectively implementation of quality education.

Books on the drive model of students as the first, third, the paragon of virtue, and constantly improve their own moral consciousness level. Positive people hexyl, teachers must take the noble morality and noble demeanor to cultivate the goods. This requires teachers to do: (1) in the speech, to the state of the society for students to be responsible to society has different views, but also not in the students to speak, to mislead students. As we said "I am the sea a spoondrift, to enable students to understand to each people living in society, the individual survival and development can not open society. And the people rowing open the ship" to enable students to realize "unity is strength" and to Actual actions and consciously safeguard the collective honor and interests. (2) in the manner, always and everywhere a teacher asked the students to do; teachers, first of all do. Teachers should enthusiastic good, let the socialist morality, fashion in the campus, in the student spread.

\section{Change the teaching concept, change the examination oriented education for quality education.}

The concept of thinking to the students the most precious is their country's future fate of concern and to the reality of life. For a long time the formation of students entering a higher school, teachers for grasping fraction and teach ideological and political course teaching, and teachers to teach the roads, the students back roads, test strip entrance education mode must be thoroughly broken. Of course, the social and economic development needs more high level of talent, the entrance examination and selection of personnel necessary, entrance education mode of existence has its rationality. However, one point is clear, however, that the social and economic development not only requires a high level of talent, but also need more talents. We face Improve the quality of the whole nation. Only when the whole nation to improve the quality, in order to promote the rapid development of the productive forces. Therefore, ideological and political teaching focus should not only to higher education, but should is to improve all students ideological understanding level, from the entrance education of the track to track of quality education. For teachers, not reduce the teaching requirements, but to improve the teaching requirements, it is necessary for teachers to spend great efforts to understand the students, improving teaching methods, textbook knowledge into the students' knowledge and ability.

With the aggravation of competition and the development of market economy, differences and characteristics become market human pursuit of things, and the destruction of examination oriented education is just students differences and qualities, so that they are difficult to adapt to the requirements of the job market. Exam oriented education enrollment as the goal, the content of Education Emphasis on IQ, contempt, body, the United States, labor aspects, especially ignored practical and hands-on ability.

From the point of view of the development trend of employment, the future more is companies and enterprises determines the employment of students. And companies and enterprises need is with independent thinking and creativity, is to solve the actual problem ability and the spirit of unity and cooperation. However, the principles of companies and enterprises and did not reflect in the current education system.

\section{Equal to the students, the closed - type teaching for the open teaching.}

Contemporary middle school students is a prominent feature of the thought of opening and the pursuit of personality equality. They don't meet to acquire knowledge from the classroom, eager to contact with society, know the society, especially social issues, in order to increase the sense of their historical responsibility. At the same time, they are eager to understand my teacher, treat others as equals, despite high and low points of students between intelligence, but disagreed with their teacher preference, equality between teachers and students, hope that their views are apropos of teacher evaluation and can have an impact on teachers and students. In the study, excellent students and backward students to help each other, there are opportunities for their performance in 
the classroom Discussed. Combined with practice, trapped under the guidance of teachers, and equal competition, promote each other. Closed type teaching can not meet the students' ideological openness and equality of personality, it is the student's field of vision in the textbooks and classroom, students think and answer the questions completely along the teachers to design good logical track teaching method to inject type, although also pay attention to make peace, but are to teachers as the center of open type teaching is the teachers' leading role and students' main body function of the organic combination of principle, in the classroom for students to open the discussion type teaching method, teachers guide students to analyze the basic facts in the express oneself See, allow different views, the views of each other, so that the students come to the conclusion that the teaching center transferred to the students, it will accelerate the level of awareness and improve the ability to think.

\section{Stimulate interest in learning, cultivate innovative awareness}

Learning interest is to create the necessary conditions for development, interest is a great power, can attract students attention, thinking and imagination, prompting students to think actively, observation and research. From the actual situation, students of politics interested or not, will directly affect the enthusiasm of thinking. If the teaching is always in a rut. Teach doctrines, back roads, "YiYanTang" indoctrination will only make students feel bored, loss of interest in the study of Ideological and political course, such teaching due to not play the main role of the students, the students can not actively active participation in the teaching process, thus it is difficult to achieve goal of cultivating students' quality. Therefore, teachers in teaching should first of creative, design vivid teaching situation, stimulate students that a strong desire to explore, so that students in a positive state of mind, so that can be conducive to the cultivation of students' creative thinking ability. For materials than the more abstract concepts and principles, in the teaching to follow from individual to general, from the concrete to the abstract human cognition rules, a simple and vivid metaphor to help students analyze and understand, increase interest in learning, to stimulate enthusiasm for learning. In the teaching process should be used recordings, videos, slides and other multi-media visual materials, fully mobilize the enthusiasm of the students Senses and make teaching more vivid, image, students' learning enthusiasm will greatly increase. Stresses such as the history of development of society productivity concept, available audio-visual media show primitive society, slave society, feudal society, capitalist society production tools, such as stone, metal tools, iron tools, machine manufacture, lets the student realize the improvement of production tools and widely used in different social production development of the important role, so that they truly understand the production tool is an important symbol of the level of development of productive forces, in order to make students more profound experience to create innovative tools of production, and promote the development of production and promote The importance of social progress. The cultivation of innovative quality is the core of quality education, is also the middle school thought political lesson teaching an important task, we should strive for the cultivation of innovative quality, to meet the needs of the development of knowledge economy and social economy.

\section{Make good use of social class, and social practice.}

Linking theory with practice, class teaching and social class with, is the junior middle school political lesson of implementation of quality education is an important way. According to the different grades, different subject, lets the student small classroom into social class, in social education environment, to make the students understand the learning of theoretical knowledge, to understand society, to adapt to the society, and continuously improve the overall quality of students. The main way is to go out and come in, please. Go out, according to the need of task, organize the students to the factory to visit, to the rural survey interview, through to the social interview survey, broaden the horizons of students, to further understand the theory of socialist construction and reform and opening up push The rapid development of economic construction in our country. 
Please come in, according to the need of the subject, please contribute in the practice of socialism, on behalf of the staff to the school to lecture, special report. Combined with the actual, held in the second classroom activities, current speech. In this way, the lively learning, in the thought political lesson learned knowledge test, obtained the sublimation, so as to stimulate students to the theory of socialist construction the pursuit of desire and the spirit of innovation, effectively improve the theory and thinking quality of students of political science, morality, the level of consciousness, good quality education. To create a life of the political class, changing abstraction, hollowing said Teaching of classroom teaching and improve the teaching effect, we must in the teaching goal, teaching content, teaching methods and means based on social life, the political class to add the source of times and life vitality, also allow students to experience the joy of life and the life and learn to behave, learn to do, learn to live.

\section{Conclusion}

Implementation of quality education in the middle school thought political lesson teaching is a long-term and arduous task, must correct guiding ideology, establish the concept of quality education; to reform the traditional teaching mode, give full play to the student's main body role; teachers to improve their own quality, guarantee the teachers' leading role; strengthening political education, optimize the quality structure. So as to improve the effectiveness of Ideological and political lesson teaching, give full play to the educational function of Ideological and political course, cultivating cross century "Four Haves".

\section{Reference}

[1] Li Jinyu. The concept of curriculum reform and innovation. Beijing: People's education press, 2003.

[2] Li Xiaowen, Wang Ying. Teaching strategy. Beijing: Higher Education Press, 2000.

[3] Feng Xin. Study and solve the problem of the new teaching material: junior middle school thought moral character. Northeast Normal University press, 2008.5.

[4] Yuan Yiping. The spark of wisdom in an open classroom. Teaching monthly: middle school edition, 2007 (5).

[8] Zhang Youlin. Situational experience to promote the development of inquiry teaching reference of middle school politics. Shaanxi Normal University publishing house 2007.6.

[9] Zhang Xiangkui. Adolescent psychology. Northeast Normal University School of network group, 2005.6. 